\title{
Originalism from the Soft Southern Strategy to the New Right: The Constitutional Politics of Sam Ervin Jr
}

\section{Logan E. Sawyer III}

Associate Professor of Law \& Director of Undergraduate Studies University of Georgia School of Law, lesawyer@uga.edu

p bSRN

\section{Repository Citation}

Logan E. Sawyer III, Originalism from the Soft Southern Strategy to the New Right: The Constitutional Politics of Sam Ervin Jr, 33 J. Pol'y Hist. 32 (2021),

Available at: https://digitalcommons.law.uga.edu/fac_artchop/1397

This Article is brought to you for free and open access by the Faculty Scholarship at Digital Commons @ University of Georgia School of Law. It has been accepted for inclusion in Scholarly Works by an authorized administrator of Digital Commons @ University of Georgia School of Law. Please share how you have benefited from this access For more information, please contact tstriepe@uga.edu. 
LOGAN SAWYER III

\title{
Originalism from the Soft Southern Strategy to the New Right: The Constitutional Politics of Sam Ervin Jr
}

\begin{abstract}
Although originalism's emergence as an important theory of constitutional interpretation is usually attributed to efforts by the Reagan administration, the role the theory played in the South's determined resistance to civil rights legislation in the 1960s actually helped create the Reagan coalition in the first place. North Carolina Senator Sam Ervin Jr., the constitutional theorist of the Southern Caucus, developed and deployed originalism because he saw its potential to stymie civil rights legislation and stabilize a Democratic coalition under significant stress. Ervin failed in those efforts, but his turn to originalism had lasting effects. The theory helped Ervin and other conservative southerners explain to outsiders and to themselves why they shifted from support for an interventionist state powerful enough to enforce segregation to an ideology founded on individual rights and liberty. It thus eased the South's integration with the emerging New Right.
\end{abstract}

Keywords: Party politics, civil rights, originalism, constitutional law, New Right

Sam Ervin Jr. spent five years on the North Carolina Supreme Court from 1949 to $1954 .{ }^{1}$ During that time, he expressed no qualms about his state's system of racial segregation, which included a dizzying array of statutes that regulated the movement, association, education, and employment of North Carolinians,

Thanks to Nancy MacLean, Kenneth Kersch, Chris Schmidt, Laura Phillips Sawyer, Lucas Boggs, Lori Ringhand, the American Society for Legal History, and the editors of the Journal of Policy History

JOURNAL OF POLICY HISTORY, Vol. 33, No. 1, 2021.

(C) Donald Critchlow and Cambridge University Press 2021

doi:10.1017/So898030620000238 
both black and white; one statute even outlawed fraternal orders that allowed blacks and whites to address one another as brother. ${ }^{2}$ Ervin's support for those invasive restrictions on individual autonomy, in fact, helped him become a Democratic US senator in 1954, when the governor appointed him to a vacancy after the presumed front-runner ruined his chances by encouraging his fellow citizens to obey the decision in Brown v. Board of Education. ${ }^{3}$ By 1966, however, Ervin regularly claimed that the Constitution prohibited racebased government programs of any kind, and he viewed the protection of individual rights from both state and federal authorities as the core of his political philosophy.

As Ervin shifted from a communitarian embrace of state power, where the federal government was the primary threat to liberty and federalism the primary protection, to a political ideology grounded on individual rights and skeptical of government authority at both the federal and state level, he faced no serious threat to his election to a full Senate term in 1956 or reelection in 1962 and 1968. Nor did that shift change his identification as a conservative. ${ }^{4}$ Ervin was instead traveling the same path as many of his constituents, who were shifting from a conservatism that Kevin Kruse has described as based on "traditionalist, populist, and often starkly racist demagoguery" to a conservatism "predicated on a language of rights, freedom, and individualism."

Ervin, however, did more than merely participate in this shift. As the constitutional theorist of the South's determined resistance to civil rights legislation through the mid-1960s, he developed and defended legal and constitutional arguments that provided a pathway he and other conservative southerners followed to this new political ideology. ${ }^{6}$ In 1956, Ervin embraced a theory of constitutional originalism that foreshadowed the approach of today's conservative movement-and then, over the ensuing decades, used it to explain to both outsiders and southerners themselves how their shifting views of state authority were not self-serving responses to federal civil rights laws or their own increasing move to the suburbs, where an interventionist state became a threat to, rather than a protector of, their privileges. ${ }^{7}$ Ervin's originalist arguments portrayed that shift as no shift at all, but instead as a consistent embrace of traditional conceptions of liberty, fundamental to American government and society, made legally binding by the Constitution.

By easing this shift to a new, individual rights-based conservatism, Ervin's constitutional arguments helped conservative southern Democrats find common ground with anti-New Deal Republicans outside the South, some of whom were exploring similar constitutional arguments, and the vast majority of whom were happy to find new allies in their efforts to turn the GOP into a 
political vehicle for the conservative movement. ${ }^{8}$ During an intensely competitive North Carolina Senate race in 1984, conservative Republican Jesse Helms, with help from Ronald Reagan, worked to associate himself with Ervin's legacy. Helms, who had made originalist noises himself as a prosegregation newspaper editor in 1963, ran ads touting his relationship with Ervin and justified his opposition to the renewal of the 1965 voting rights act by appealing to Ervin's constitutional expertise. ${ }^{9}$ When asked about Helms's efforts, Ervin said he planned to vote the straight Democratic ticket, just as he always had. But he also declined to endorse either candidate or deny his relationship with Helms. "I'll do anything for Jesse Helms except voting for him on the Republican ticket. . . We've been friends for years." The only complaint Ervin was willing to lodge against Helms was that he "should have stayed in the Democratic Party and helped me."10

Originalism's role in redefining southern conservatism and thus helping to produce the contemporary Republican Party has not received its due for at least two reasons. First, with a small but growing number of exceptions, discussions of originalism past have focused on the theory's emergence from academic debates in the 1970s. ${ }^{11}$ Second, Ervin failed in what he saw as his most important tasks in the 1950 s and 6os: protecting segregation and the power of the Democratic Party in the South. ${ }^{12}$ That failure can make Ervin's embrace of originalism appear to be the last, desperate gasp of a dying political order. But originalism was much more than a post-hoc rationalization for the immediate political goals of Ervin and his political allies. Among other things, it was an ideological and rhetorical pathway through which a potentially antagonistic relationship between southern Democrats and anti-New Deal Republicans became natural alliance. It guided southern democrats to a new political identity, and thereby helped support, even create, the durable shift in governing authority formalized by the election of Ronald Reagan in 1980. ${ }^{13}$ Recovering the way Ervin defined, deployed, and redefined originalism shows that a constitutional theory generally understood to be a product of the New Right actually helped create that coalition in the first place.

\section{FROM THE COURT TO THE SENATE}

When North Carolina Democratic senator Clyde Hoey died in his office in the US Senate five days before the Supreme Court decided Brown v. Board of Education, Ervin was not the governor's first choice to fill Hoey's seat. The appointment fell to Ervin because he had kept clear of factional conflict within North Carolina's dominant Democratic Party and because the governor's 
presumed frontrunner for the appointment had publicly suggested that the state should begin desegregating its schools in response to the decision. Ervin, however, seemed like the ideal person to defend segregation in post-Brown Washington. A graduate of the University of North Carolina and Harvard Law School as well as a state Supreme Court justice, Ervin had the professional credentials and expertise to mount a constitutional critique of Brown and any other federal challenge to segregation. ${ }^{14}$

Although Ervin ultimately failed to protect legally enforced segregation from federal law, he spent his first decade in office aggressively defending it alongside the other Democratic senators and representatives who had organized themselves into the Southern Caucus. He attacked Brown at his first press conference, and in his first major speech he gave an extended critique of the decision. ${ }^{15}$ A year later Ervin helped draft the Southern Manifesto-the Southern Caucus's formal response to Brown-and then used his seat on the Judiciary Committee and his chairmanship of the Subcommittee on Constitutional Rights to oppose civil rights legislation. ${ }^{16}$ In his first decade as a senator, he opposed every civil rights bill between 1954 and his retirement in 1974, and participated prominently in filibusters of the Civil Rights Act of 1964, the Voting Rights Act of 1965, and other civil rights legislation."17

Ervin was stalwart in his defense of segregation, but the arguments he used changed significantly over time. By 1965, Ervin's constitutional critiques of civil rights legislation had made him the most visible and consistent defender of originalism in American politics. ${ }^{18}$ Ervin, however, was not an originalist when he was on the North Carolina Supreme Court. None of his opinions explicitly used the originalist method Ervin later claimed was the only legitimate method of constitutional interpretation. Ervin did not deny that original meanings were relevant, yet his approach is best described as traditional, combining attention to text, history, prudence, principle, and a heavy emphasis on interpreting existing precedent to resolve constitutional disputes. ${ }^{19}$

Nor was Ervin's initial critique of Brown originalist. His attack on the decision in an April 1955 speech at the Harvard Club of New York, published in Vital Speeches of the Day, emphasized the Court's use of social science data and its rejection of precedent. ${ }^{20}$ To be sure, Ervin emphasized the genius of those who drafted the Constitution-but all methods of constitutional interpretation acknowledge that original meaning is relevant to constitutional analysis. ${ }^{21}$ Originalism goes further, claiming that the intention of the Founders or the original understanding of the document is binding law and capable of deciding important, contested issues of constitutional law. ${ }^{22}$ Yet Ervin did not 
make that claim in this speech, and in fact never mentioned the drafters or ratifiers of the Fourteenth Amendment. A Supreme Court Justice, said Ervin, must "lay aside his personal notions of what the law ought to be, and to base his decisions on established legal precedents and rules." 23 The Brown court had erred because it "repudiates solely upon the basis of psychology and sociology the interpretation placed upon the 14th amendment in respect to racial segregation by Federal and State courts, the Congress itself, and executive branches of the Federal and State Governments throughout the preceding 86 years." 24

If Ervin was seeking the best legal argument against Brown, he was wise not to adopt originalism. The theory had virtually no support among legal academics, was most closely associated with the aggressive use of judicial review, and appealing to it was unnecessary to make Ervin's point. Legal academics associated originalism with the vilified Four Horsemen who opposed the New Deal and the reviled decision in Dred Scott v. Sanford. ${ }^{25}$ On the Supreme Court, only Justice Hugo Black was arguably a proponent of the approach. ${ }^{26}$ But Black had joined the Brown decision, and in 1955 his jurisprudence was most closely associated with efforts to protect accused Communists and criminal defendants. ${ }^{27}$ There were arguments-strong, but also contested-that the original intentions of the drafters of the Fourteenth Amendment were inconsistent with Brown. ${ }^{28}$ But because everyone agreed that original intent was relevant to constitutional adjudication, calling on originalism for support was unnecessary. ${ }^{29}$ In addition, Ervin could easily find nonoriginalist grounds to criticize Brown and the Warren Court, including a long-established interpretive tradition that included some of the most prestigious jurists and academics of the previous seven decades: process jurisprudence.

Process jurisprudence was the dominant theory of constitutional interpretation during the 1950 and ' 60 s. It built on a respected tradition of judicial deference to legislative majorities that its supporters traced from Justices Oliver Wendell Holmes Jr., Louis D. Brandeis, and Felix Frankfurter. ${ }^{30}$ Its emphasis on the deference that the courts owed to the other two branches of government, plus its insistence that judicial review was justified only if the principle at stake was clear and well established, could be-and wasdeployed to criticize Brown. ${ }^{31}$ In a lecture he delivered at Harvard in 1958, Judge Learned Hand criticized the Warren Court and Brown in particular because the Court was acting as "a third legislative chamber," illegitimately substituting its own value judgments for those of Congress. ${ }^{32}$ A year later Herbert Wechsler argued that the Court in Brown had failed to provide the 
kind of "neutral principles" that alone made judicial review legitimate. ${ }^{33}$ In the mid-1960s and later, both Alexander Bickel and Philip Kurland criticized the Warren Court on similar grounds. ${ }^{34}$

Ervin thus did not need originalism to make a strong legal argument against Brown, and using it as the basis of his critique would have made his argument weaker, not stronger, in the eyes of legal professionals. Ervin correctly saw that he was better off using process jurisprudence's focus on the careful use of precedent to identify underlying principles to critique Brown. But as Ervin's concerns increasingly shifted from finding the legal argument most convincing to legal professionals to finding the legal argument most likely to help him solve an increasingly difficult and complex set of political challenges, he discovered some unique virtues in originalism.

\section{FROM PRECEDENT TO ORIGINAL INTENT}

Ervin began to change the jurisprudential basis of his challenge to desegregation just one year after his Harvard Club speech, when he helped draft the Southern Manifesto. The Manifesto, formally entitled the Declaration of Constitutional Principles, was the Southern Caucus's official response to Brown. Written by the best lawyers in the caucus, it used constitutional arguments for a political purpose: to attract sympathy from moderates, in the North and South, while simultaneously stoking just enough segregationist anger to prevent a third-party challenge to the Democratic Party in the South. ${ }^{35}$ The Southern Caucus had long used constitutional arguments and appeals to the Founding Fathers to protect segregation, but as Ervin turned his focus from finding the best legal argument against Brown to helping his colleagues develop constitutional arguments that could support a successful political coalition, his jurisprudence also shifted. ${ }^{36}$ When the debates over the 1957 Civil Rights Act started the next session, Ervin was ready to claim that originalism was the only legitimate method of constitutional interpretation.

Work on the manifesto began in the shadow of the 1956 elections - and in the wake of a series of political events that were generating increased pressure for federal civil rights legislation and were also forcing southern politicians to clarify their position on the "race issue." For decades southern political leaders had worried about segregation's survival in the face of a New Deal political coalition that welcomed African American votes in the North and in the face of the ideological pressures of World War II and then the Cold War. ${ }^{37}$ Those worries increased in the aftermath of Brown in 1954, the murder of Emmett Till and the Montgomery Bus Boycott in 1955, the riots caused by Autherine Lucy's 
arrival at the University of Alabama in 1956, and other events. To resist the pressure for federal legislation, Southern Caucus members needed to create a legislative coalition with Republican senators outside the South who were uncomfortable with overtly racist rhetoric. But they also had to defend segregation vigorously enough to prevent a challenge from a reactionary third party, like the one launched by the States Rights Party in $1948 .^{38}$

As they sought those twin goals, Ervin and other members of the Southern Caucus offered normative defenses of segregation. They sometimes argued that it was a broadly supported method of preserving racial peace and recognized divinely mandated racial differences. Others stressed cultural differences and emphasized the need for southerners to address the problems of racial divisions through their own (achingly slow) process. But those appeals to southern cultural norms were not their core argument. ${ }^{39}$

As Keith Findley has documented, the caucus's primary strategy was to use constitutional arguments and an associated interpretation of American history to portray themselves as waging a battle to protect traditional American political institutions and the liberty those institutions protected. ${ }^{40}$ They based these arguments not on memories of the old South, reconstruction, or the Civil War; the embrace of that history would undermine their efforts to attract votes from senators outside the South. Instead, caucus members put memories of the American Revolution at the center of their arguments and adopted the classical republicanism of the Founders for their cause. Caucus members, like the founding fathers before them, were brave patriots fighting against the concentrated power of "special interest activism" and a distant, centralized government that conspired to deprive Americans of their traditional and legally guaranteed liberties. ${ }^{41}$

Ervin had every reason to embrace the caucus's strategy. His personal support for segregation was sufficient reason to oppose civil rights legislation, as he regularly made clear. ${ }^{42}$ But the political situation he faced in North Carolina made the caucus's strategy attractive as well. The conflict between moderates and reactionaries was as intense in North Carolina as anywhere else in the South. ${ }^{43}$ Moderates were a powerful force in North Carolina in the $1950 \mathrm{os}$ and 6os. In fact, only two members of the state's congressional delegation signed the Southern Manifesto immediately, and three members ultimately declined to sign-North Carolina thus had more nonsigners than any state other than Texas. ${ }^{44}$ The presumed frontrunner for the vacant Senate seat had urged the kind of moderate response that the drafters of the Southern Manifesto feared. The state's other senator, Kerr Scott, originally took the same position. ${ }^{45}$ When Virginia's governor held a conference on interposition 
in 1956-a constitutional argument that opponents had a difficult time distinguishing from nullification-North Carolina's governor attended the conference but then declined to formally endorse the theory. ${ }^{46}$ North Carolina largely avoided massive resistance-the shuttering of schools and interposition-and instead opposed desegregation with pupil placement plans and efforts to negotiate with the African American population. Racial demagoguery and outright threats were relegated to a less overt role. ${ }^{47}$

Yet North Carolina also had powerful reactionary resistance. A group called the North Carolina Patriots formed to fight integration in the state and took clear aim at politicians who did not vigorously oppose the Court's desegregation orders. They targeted all three congressmen who refused to sign the manifesto, defeating two and pushing the third to pursue a racebaiting campaign that saved his seat. ${ }^{48}$ The group's 1957 Blue Print for Resisting Integration encouraged its chapters to remind officials that the Patriots had caused those electoral defeats. ${ }^{49}$ They pushed Senator Scott to embrace the state's student-choice program, which was an effort to stymie the Brown decision, even though he had opposed defying the Court order in his 1954 campaign..$^{50}$ As much as any other members of the Southern Caucus, Ervin needed to show reactionaries that he was one of them without frightening moderates.

Combining appeals to Founding Era republicanism and constitutional law offered Ervin a clear path to do that, just as it did other members of the Southern Caucus. These appeals attracted the support of moderates for the same reasons that pupil placement plans did: they protected segregation through the traditional legal mechanisms and avoided extralegal violence or overtly white supremacist rhetoric. ${ }^{51}$ Those appeals also simultaneously made clear to reactionaries that Ervin and his colleagues would not compromise in their defense of segregation. As Ervin regularly repeated, if a bill was unconstitutional, senators and representatives had a duty to oppose it regardless of its putative values. ${ }^{52}$ No political horse trading would be permissible. But perhaps more important, when Ervin defended what he defined as traditional American institutions and liberties, he was defending ideals that racial reactionaries had themselves defined as the product of white supremacy. Thus, they would have interpreted his defense of those ideals as a defense of white supremacy itself.

The leader of the North Carolina Patriots, W. C. George, explicitly embraced white supremacy and tied it to a defense of traditional constitutional values that raised originalist themes. ${ }^{53}$ "All the evidence that I know about," wrote George, a professor at the University of North Carolina School of 
Medicine, "indicates that the Caucasian race is superior to the Negro race in the creation and maintenance of what we call civilization." ${ }^{44}$ Brown raised two "fateful questions," according to George: "Are we going to have a white or a mulatto posterity?" and "Are we going to have a Constitution as the foundation and safeguard of our liberties ...?" ${ }^{55} \mathrm{He}$ expected both whiteness and the Constitution to win out, in part because they were linked. "Our people," he wrote, "reared in a tradition of freedom, are ordered to accept the dissolution of the Bill of Rights with 'all deliberate speed." 56 They would not, he believed, abandon those liberties-liberties that George, like Ervin, traced to Americans' Anglo-Saxon forefathers. "Since the year 1215," George asserted, "when our American [sic] forebears forced King John to sign the Great Charter, the forerunner of our Constitution, Anglo Saxon peoples have not tolerated tyranny for long." 57 "Constitutional government," he wrote elsewhere, "that helps to restrain the growth of tyranny" was one of the "conceptions and achievements of the white race." 58 To reach its decision in Brown, the Court had to "reverse the understanding [the Fourteenth] Amendment had at the time of its adoption and the meaning that has been upheld by the courts until now." 59 Because the Court had ignored "constitutional processes," he argued, "morally and constitutionally the law of the land remains at it was in 1954," before the ruling. ${ }^{60}$ The people must take action to prevent the Court from taking such steps. "Otherwise [they] will lose the very foundation of their liberty, that is, the Constitution as written and adopted." ${ }^{1}$

With looming pressure to appeal to moderates, reactionaries, and Republicans, Ervin enthusiastically embraced the Southern Manifesto's approach, even pushing the document's primary drafter, Richard Russell, to further emphasize analogies between the southern fight against Brown and the Founding Fathers' fight against a distant and despotic British government. ${ }^{62}$ In his suggested edits, Ervin urged Russell to point out that the Founders had framed a written constitution in response to the "tragic truth" of history that no one can be trusted with unlimited power." ${ }^{63}$ He even wanted Russell to add an explicit statement supporting the theory of originalism: "In the very nature of things," he suggested that Russell add, "the meaning of a written constitution is fixed when it is adopted, and is not different at any subsequent time." 64

The final version of the manifesto did not incorporate those suggestions. It certainly makes arguments based on original intent. For example, the manifesto claims that "the debates preceding the submission of Fourteenth Amendment clearly show that there was no intent that it should affect the systems of [segregated] education maintained by the states" because "the very Congress which proposed the amendment subsequently provided for 
segregated schools in the District of Columbia."65 The document was nevertheless not expressly originalist. It never identified a preferred interpretive theory. Instead, it wove together arguments from original intent, precedent, pragmatism, and structure: Plessy vs. Ferguson, reliance interests by many states, the chaos and confusion produced by the decision, and its destruction of "amicable relations between the white and Negro races" were all part of it critique of Brown. ${ }^{66}$

Although the manifesto did not explicitly embrace originalism, it was a turning point for the constitutional theorist of the Southern Caucus. For decades, Richard Russell, John Stennis of Mississippi, and other members of the committee that drafted the Southern Manifesto had been using constitutional arguments to ward off civil rights legislation. ${ }^{67}$ Ervin's commitment to help them succeed in the newly intensified fight against civil rights legislation meant his focus shifted from finding the best legal argument against federally mandated desegregation to identifying the best way to solve the Southern Caucus's delicate political problem. That new focus led Ervin to see that originalism's weakness in professional legal argument was outweighed by its strength in political debate. Originalism helped connect revered American figures and traditions to segregationist arguments. It thus made the defense of segregation more appealing to both northern senators and southern moderates while simultaneously signaling to reactionaries that the Southern Caucus their racialized understanding of core American values and would never compromise in defense of the South's traditional institutions. Those advantages alone may have been enough to lead Ervin to embrace originalism, but as the fight for civil rights increasingly turned from the courts to Congress, he found the theory had a another advantage: it allowed Ervin and his colleagues to raise constitutional objections to civil rights bills even in the face of increasingly convincing claims that the bills were constitutional under recent Supreme Court precedent.

\section{FROM COMMUNITY VALUES TO INDIVIDUAL RIGHTS}

Following his work on the Southern Manifesto, Ervin began to consistently defend originalism as the only legitimate method of constitutional interpretation. In a subcommittee hearing on the 1959 Civil Rights Act, he argued that "a court has the right to reverse itself when its original decision on a constitutional question was not in conformity with the intention of the persons who drew and ratified the constitutional provision. I deny that a court has a right to place an interpretation upon the Constitution at variance with the intention of 
those who framed and adopted the Constitution." ${ }^{68}$ Four years later, in Judiciary Committee hearings on the 1964 Civil Right Act, Ervin argued that the Fourteenth Amendment's meaning was determined by "the intent of those who framed and ratified it." The "fundamental principle of constitutional construction," he said, is "to give effect to the intent of the framers of the organic law and the people adopting it." 69

Ervin's embrace of originalism after 1956 made him a particularly powerful opponent of federal civil rights laws, particularly the Civil Rights Acts of 1957, 1960, and 1964. To stop or weaken those laws, Ervin and his colleagues sought the support of anti-New Deal Republicans, who were less attracted to constitutional arguments about federalism than to claims about individual rights-particularly property rights and the right to trial by jury. Originalism helped make Ervin's constitutional arguments about individual rights more effective in two ways. It helped Ervin explain how a former North Carolina Supreme Court justice, who in 1954 had never questioned the authority of the state to aggressively exercise its police power to tightly control property rights and rights of association in the name of segregation, became a champion of property rights, individual rights, and limited government: not inveterate racism, but principled dedication to the Constitution. It also allowed Ervin to defend his constitutional arguments against the powerful charge that the civil rights laws were constitutional under existing Supreme Court precedent.

Ervin deployed very similar arguments against the Civil Rights Acts of 1957,1960 , and 1964. He opposed them not because he was a racist but because he was protecting well-established and legally binding constitutional traditions. He made structural arguments about federalism and the separation of powers, pointing to a variety of constitutional provisions (especially those in article 2 and the Fourteenth Amendment), as well as arguments concerning individual rights (like the right to a jury trial). He then strengthened those arguments by characterizing them as an expression of a political philosophy that he attributed to the Founders. Traditional American institutions and ideals, he argued, were under attack from an overweening federal government and particularistic interest groups, above all the "agitators" at the NAACP. Southern senators were the defenders of constitutional principles that dated to the nation's founding and that were legally binding. ${ }^{70}$

Ervin first used this strategy to fight Title IV of the Eisenhower administration's 1957 Civil Rights Act. The impetus for the 1957 act, the first civil rights legislation since Reconstruction, was the administration's desire to attract African American votes in northern states, and its specific goal was to protect black suffrage. The bill easily passed in the House and strong 
Republican support meant that a southern filibuster might fail, so the Southern Caucus sought to remove the most threatening parts of the bill: Titles III and IV. ${ }^{71}$ A broad array of senators challenged Title III on policy and legal grounds. Authorizing the US attorney general to initiate civil proceedings on behalf of individual voters who had been denied the right to vote, as Title III did, was unnecessary and an unwise centralization of power that could lead to military enforcement of school desegregation. ${ }^{72}$

Ervin led the charge against Title IV, which allowed contempt proceedings in any civil rights case brought by the attorney general to be tried by a federal judge rather than a jury. The administration argued that this change was necessary because southern juries might refuse to convict state officials who violated civil rights laws. ${ }^{73}$ Ervin denied southern juries would do any such thing, ${ }^{74}$ but his primary argument was that dishonest interest groupsnamely, the NAACP-and power-hungry bureaucrats were attacking the traditional protections of freedom and liberty. The bill, he claimed, was "deliberately designed" to give the attorney general "autocratic power" by robbing people in civil rights disputes of the "basic and invaluable safeguards created by the Founding Fathers and Congress to protected all Americans from bureaucratic and judicial tyranny," including the right to a grand jury indictment, the right to avoid double jeopardy, and most important, the right to a trial by jury. ${ }^{75}$ King John used similar approaches against his English subjects and by King George against his American subjects. ${ }^{76}$ By breaching those rights, the bill undermined free institutions, removing "the thin wedge of reserved power which separates our legal system from the monolithic totalitarian system of justice which prevails behind the Iron and Bamboo Curtains."77

Ervin transformed these historical and normative claims into a constitutional one by deploying originalism. ${ }^{78}$ Crafting his constitutional argument was not easy, as he was unable to cite any case that identified a constitutional right to a jury trial in a contempt hearing in which the government was a party. In fact, he did not even attempt to make an argument based on precedent. Nor could Ervin point to any text in the Constitution that referred to this right. As he noted, the Constitution mentioned equity hearings only once, in a jurisdictional provision, and it limited the right to a jury trial to criminal cases. ${ }^{79}$ But the original intent of the founders and ratifiers, Ervin argued, made the bill unconstitutional.

The Founders, he argued, did not extend the right to jury trial past criminal trials because when the Constitution was adopted, equitable remedies were used only to protect property rights. ${ }^{80}$ According to Ervin, the Founders 
believed that requiring jury trials in criminal cases was sufficient to thwart those who "would convert courts of equity into courts of star chamber" by "extending the powers of equity beyond their ancient limits." Moreover, he continued, history showed that the Constitution never would have been ratified if Americans had understood that they could be "robbed of their right to trial by jury by perverting injunctions and contempt proceedings from their historical uses to the field of criminal law." These intentions of the Founders and the understanding of those who ratified the Constitution, he concluded, meant that when the Constitution guaranteed that "the trial of all crimes shall be by jury," it did more than ensure jury trials in criminal trials. It also "necessarily invalidates by implication any proposal to rob Americans of their right to jury trial by extending the injunction and contempt processes of equity to the criminal field." 81

Ervin used a similar approach in his fight against the 1964 Civil Rights Act. ${ }^{82}$ The 1964 Civil Rights Act included a jury trial exemption for contempt proceedings in civil rights cases-just like the 1957 Civil Rights Act had-and Ervin and his colleagues attacked that provision just as they had before. But in response to the Birmingham protests, the murder of Medgar Evers, and Martin Luther King Jr.'s March on Washington, the Kennedy administration had made the 1964 Act into much more than just a voting rights act: it was a direct attack on segregation. Title II prohibited segregation in any place of public accommodation with a substantial relationship to interstate commerce. ${ }^{83}$ Unwilling to compromise on that issue, hardline members of the Southern Caucus, including Ervin, focused on attracting enough Republican votes to sustain a filibuster. ${ }^{84}$ To appeal to Republicans, the caucus did as it had before: obfuscate racial issues and claim that the bill's constitutional infirmities would produce federal and bureaucratic tyranny. ${ }^{85}$ As before, the caucus claimed that it was fighting to protect the individual rights that the nation's Founding Fathers had enshrined in the Constitution. ${ }^{86}$

Since the right to jury trial was immaterial to Title II, the Southern Caucus grounded its opposition in another set of individual rights: the rights to property and free association. Together, those rights allowed individual Americans to discriminate in their private lives, should they so choose. ${ }^{87}$ By prohibiting discrimination, the caucus argued, the federal government interfered with the rights of property owners to decide how to use their own property. It also prevented individuals from choosing who they wanted to associate with. Those arguments, of course, were directly contrary to their recent support for state segregation laws that interfered with both property 
and associational rights—but they seemed unconcerned about the contradiction. ${ }^{88}$

As before, Ervin played a leading role in defending these arguments and did so, in part, by deploying originalism. In July and August 1963, Ervin used his position on the Judiciary Committee to turn the Senate hearings on the Civil Rights Act into a six-day debate with Attorney General Robert F. Kennedy over the bill's constitutionality-a debate the newspapers dubbed "The Sam and Bobby Show." He then formalized his arguments in an article published in the North Carolina Law Review. ${ }^{89}$ In both places, Ervin deployed multiple modalities of constitutional argument-precedent, constitutional structure, and text. He pointed to the Founders as honored authorities and identified principles of American democracy. But every time he identified an approach to constitutional interpretation, he identified originalism. He told Kennedy, for example, that it is only the power to interpret the Constitution that "belongs to the Court, and that is only the power to ascertain and give effect to the intent of those who drafted and those who ratified the Constitution. ${ }^{90}$ He repeated those claims in the North Carolina Law Review and elsewhere, including a speech at the University of Alabama Law School in April 1965. It was "as clear as the noonday sun," he declared there, that the Supreme Court's role "is simply to ascertain and give effect to the intent of [the] framers [of the Constitution] and the people who adopted it." ${ }^{\prime 1}$

Ervin's originalism was particularly useful in his debate with Kennedy and others over the constitutionality of the 1964 Civil Rights Act, because it allowed him to counter the powerful argument that recent precedent made clear the Supreme Court would uphold the law (as it later did). ${ }^{92}$ "At the very beginning," Ervin wrote in the North Carolina Law Review, "I must declare my opposition to those who hold that a Senator should ... [rely] on the Supreme Court to supply the judgment as to the constitutionality or unconstitutionality" of the Civil Rights Act. ${ }^{93}$ "It is up to the Congress as a whole," he insisted, "and to each individual Representative and Senator to remember his oath [to uphold the Constitution] and to protect the original meaning of the Constitution." 94

Ervin used originalism to challenge nearly every section of the bill, but he focused particularly on Title II's prohibition of segregation in places of public accommodation. Ervin argued that Title II was unconstitutional because it went beyond Congress's authority both to regulate interstate commerce under article 1, section 8 , and to prohibit discrimination under the Fourteenth Amendment's equal protection clause. Wickard v. Filburn had established that the federal government could use its commerce power to regulate goods 
that affected a national market-but that was quite different, he argued, from interfering with the rights of a business owner to decide whom to hire or to whom he would sell. ${ }^{95}$ According to Ervin, the equal protection clause did not support Title II because the Fourteenth Amendment's language as well as long-established precedent showed that the clause applied only to "state action," not the action of private citizens. ${ }^{96}$

These arguments are arguments about federalism, not individual rights. Individual rights arguments focus not on whether the federal government can regulate a particular behavior, but on whether that behavior can be regulated at all. The arguments Ervin advanced against the 1964 Civil Rights Act did not make that claim. If Title II exceeded Congress's authority either because a prohibition on segregation in places of public accommodation was not a legitimate regulation of interstate commerce or because that prohibition regulated private rather than state action, it would mean that Congress could not regulate segregation. But it would say nothing at all about whether the states could pass the exact same kind of antidiscrimination law under their police power.

Ervin typically argued that the primary problem with the 1964 Civil Rights Act was its unconstitutional extension of federal power. ${ }^{97}$ But he wove those federalism arguments so tightly together with his arguments about the bill's violation of property rights, associational rights, and the "right to discriminate" that it is hard to untangle the different strands of his critique. ${ }^{98}$ In a passage in his North Carolina Law Review article that exemplifies the intertwined nature of these arguments, Ervin claimed that the bill was "revolutionizing our traditional understanding of the meaning of liberty within the American Federal System." ${ }^{\prime 9}$ He achieved this integration of federalism and individual rights arguments by building on long-standing arguments that the primary importance of federalism was that it protected individual liberty. "The reason for the preservation of the federal system," Ervin wrote, "is that that system is the best guarantor of our fundamental liberties." 100 To support this idea, Ervin cited not only existing precedent, but also a 1963 New Republic article by Yale law professor Robert Bork, who called for more debate on the "cost of freedom that must be paid for such legislation [Title II], and the morality of enforcing morals through law." 101 Echoing Bork's analysis, Ervin wrote that the "chief substantive demerit of proposed civil rights legislation [was] the loss of traditional liberty guaranteed by, among other things, the federal system, in an attempt to legislate equality." 102

This argument shifted the critique of the bill away from overtly racist arguments and toward grounds that would have been particularly appealing to 
conservative Republicans, whose thirty-three votes held the balance of power in the Senate. ${ }^{103}$ Nevertheless, this strategy failed to achieve its primary goal of blocking the bill. After fifty-four days, the Senate voted to end the Southern Caucus's filibuster-but even then Ervin did not give up the fight, joining South Carolina senator Strom Thurmond in exhausting the amendment process before the act was finally brought to a vote. ${ }^{104}$ The 1964 Civil Rights Act passed the Senate, with only Barry Goldwater and four other GOP senators joining the caucus in voting against it. ${ }^{105} \mathrm{~A}$ year later Ervin and other caucus members waged a similarly doomed battle against the 1965 Voting Rights Act. Despite these failures, Ervin's fight against civil rights legislation had important impacts. As efforts to oppose new forms of segregation continued-particularly segregation created by white flight to the suburbs-the arguments that these southern senators developed and that Ervin honed would remerge. ${ }^{106}$ But in the future, these arguments would not be limited to matters of segregation.

\section{ERVIN, ORIGINALISM, AND THE NEW RIGHT}

Ervin's political world changed rapidly after the passage of the 1964 Civil Rights Act. One transformation was caused by the 1965 Voting Rights Act, which substantially increased the political power of African Americans and thus led even some of the loudest practitioners of racial demagoguery to adopt more inclusive rhetoric. Thurmond of South Carolina, Herman Talmadge of Georgia, and George Wallace of Alabama all openly sought African American votes after these political and societal transformations. ${ }^{107}$ Ervin followed a similar path. Even after his retirement, he continued to believe that the 1965 Voting Rights Act was unconstitutional, but he abandoned his opposition to Brown, belatedly admitting the decision was correct. ${ }^{108}$ Ervin's political context was also reshaped by changes in the political economy of North Carolina and the nation that created a new conservative politics in increasingly affluent suburbs, especially in the Sun Belt. There, an emphasis on business development and property rights undermined labor unions and racial liberalism and helped create the New Right. ${ }^{109}$ The marriage of constitutionalism, originalism, and individual rights that Ervin used in his fight against the 1964 Civil Rights Act failed to stop that legislation, but it did help Ervin adjust to those new political challenges.

Ervin certainly did not back away from originalism after 1964. For the rest of his career, in floor debates, hearings, and public speeches, he defended originalism as the only legitimate method of constitutional interpretation. He 
based his support of Warren Burger's nomination as Chief Justice of the Supreme Court, for example, on his perception of Burger as someone who was willing "to lay aside his personal notions of what a constitutional provision ought to say and to base his interpretation of its meaning solely upon its language and history." ${ }^{110}$ The appointment of such a justice, Ervin believed, would "begin a return to constitutional government in the United States as far as the Supreme Court is concerned." ${ }^{111}$ In a 1970 debate with former attorney general Ramsey Clark, Ervin argued that "the function of the Court is simply to ascertain and give effect to the intent of those who framed and ratified the provision in issue." ${ }^{112}$ In a 1981 article in the conservative journal Modern Age, he argued that the Supreme Court had only the power to interpret the Constitution, which consisted of "the power ... to determine the meaning of the Constitution as established by the Founding Fathers." ${ }^{113}$ He cited for support recent books by Raoul Berger and Lino A. Graglia, two scholars universally accepted today as early originalists. ${ }^{114}$

Ervin's emphasis on the constitution, and originalism in particular, helped him navigate the new racial politics of the Democratic Party in the South. A key part of that shift was Ervin's adoption of the "color-blind" interpretation of Brown. In 1963, Ervin endorsed Fourth Circuit judge John Parker's conclusion that Brown did not require racially mixed schools; it only prohibited the government-enforced racial separation. ${ }^{115}$ Thus interpreted, Brown stood for the proposition that the Fourteenth Amendment prohibited all race-based government programs, school segregation as well as race-based programs intended to ameliorate racial inequality. The Amendment thus prohibited, Ervin argued, both school busing in the 1970s and affirmative action. ${ }^{116}$ In 1985, when Ervin finally formally explained how he had shifted his view of Brown, he justified his reversal with originalism. His careful study of the debates surrounding the passage of the Fourteenth Amendment had convinced him the decision was consistent with original intent of the amendment's framers. ${ }^{117}$

Originalism also helped align Ervin's political philosophy with the individualist, right-based conservatism around which Southern Democrats and anti-New Deal Republicans were congregating. ${ }^{118}$ By the 1980s, Ervin had abandoned the communitarian support for state power that he had supported as a judge and adopted instead a political rhetoric centered on individual rights. After 1964, Ervin increasingly emphasized that government's core purpose was to protect individual freedom, which he consistently defined as freedom from government. Government officials - judges, elected officials, and others-were bound to protect the structural constitutional limits like 
federalism and separation of powers that the founders used to protect that freedom. But the Constitution's direct protection of individual liberty in the bill of rights increasingly moved to center stage in Ervin's rhetoric. By the 1970s the First Amendment's free-speech clause was a favorite talking point, and he often tied his political philosophy to it. In their remarkable wisdom, Ervin declared, the Founding Fathers had limited the authority of government in order that Americans might be protected from harmful policies (such as using busing to integrate schools) and wrong-headed social theories (such as those that justified the Miranda warning). ${ }^{119}$ By defending these traditional and established, if not timeless, principles, Ervin positioned himself in opposition to the tyranny he said would occur as bureaucrats and activist judges imposed faddish, academic theories that he argued would advance particularistic interests rather than liberty for all. Ervin justified his shift from a communitarian embrace of segregation to an individualist protection of property rights by claiming that his shift was no shift at all. Just as he had in his attack on the constitutionality of the Civil Rights Act of 1964 and before, he argued that his defense of individual rights was nothing but the product of his principled commitment to the traditional American values that the Constitution made legally binding. ${ }^{120}$

Ervin's originalism had not only rhetorical resonances with the language of the emerging New Right, but it also had substantial overlap with conservative's policy concerns. That overlap was not complete. Ervin recognized that the Constitution sometimes had unclear implications for current controversies or had no implications at all. He sometimes found that the Constitution required what could be seen as liberal results. To the chagrin of religious conservatives, he fought to allow individual taxpayers to challenge government funding of religious schools and argued that once the Court heard such a case, the Constitution's original meaning would require the Court to invalidate those funding laws. ${ }^{121}$ Ervin also regularly defended the rights of the accused on constitutional grounds. ${ }^{122}$ "No knock" warrants, he claimed, violated the Fourth Amendment, and preventive detention for particularly dangerous accused criminals violated the Sixth Amendment. ${ }^{123}$ Perhaps most notably, as chairman of the Senate Subcommittee on Constitutional Rights, Ervin fought for individual rights in a variety of contexts on behalf of a variety of interests. ${ }^{124}$ But generally, and almost always on the most important issues, his originalist interpretation of the Constitution had implications that overlapped with the interests of the emerging New Right. He found Miranda v. Arizona, busing to achieve racial balance, and Roev. Wade inconsistent with the original intentions of the Founders as expressed in the Constitution. ${ }^{125}$ His 
concern with protecting the original understanding of separation of powers, he explained to the Board of Directors of the National Association of Manufacturers in 1968, led him to oppose both an activist judiciary and the National Labor Relation Board's efforts to protect labor unions from right to work laws. ${ }^{126}$

Exemplary of the way Ervin's originalism fit with the ideas and interests of the emerging New Right was his speech against the Dirksen Bill in 1966, one year after he and the Southern Caucus lost their fight against the Voting Rights Act of 1965. Senate minority leader Everett M. Dirksen's bill proposed a constitutional amendment that would allow school administrators to provide for voluntary student prayer. Given Ervin's criticism of the Court's decision to prohibit prayer in public schools in 1962 and 1963, many expected him to support Dirksen's bill, along with the forty-nine other senators who ultimately voted for it. Instead, Ervin spoke out against the amendment, citing the Founders' vision of the separation between church and state. ${ }^{127}$ Critics found it inconsistent that an opponent of civil rights would stand up for civil liberties, but Ervin saw no contradiction. He claimed that his support for the separation of church and state and his opposition to civil rights legislation both resulted from his veneration of the Constitution. His opposition to the Dirksen Bill, Ervin said during one of his most noted speeches on the Senate floor, was motivated by his "devotion to local self-government and individual freedom." And it was that same devotion that led him to oppose two other bills that same session. The first was the "federal forced housing law," commonly known as the Civil Rights Act of 1966, which barred racial discrimination in the sale and rental of housing. The second bill was to repeal section 14(b) of the TaftHartley Act of 1947, the provision that protected the "right to work," which was a primary target of labor unions. ${ }^{128}$

\section{CONCLUSION}

The originalism Ervin espoused for almost his entire career as a US Senator and afterward was not a simple rejection of the Warren Court or its rights revolution. Nor was it a simple fig leaf for a set of conservative policy positions. After 1965, Ervin regularly supported and sometimes even fought to extend the Warren Court's individual rights-based decisions on originalist grounds, particularly in the areas of religious freedom and free speech. And he never abandoned the Democratic Party. But his originalism nevertheless had important implications for the rise of a powerful conservative movement centered on the Republican Party. It provided an ideological pathway that made a set of 
specific political issues appear to be naturally connected. Among other ideas, opposition to bureaucratic government, support for free markets, religion, and traditional social norms, and a tight association among property rights, economic individualism, and liberty were linked together through Ervin's historical discourse then made binding law by his originalist interpretation of the Constitution. Those positions could thus be presented not as contestable and self-interested policy preferences, but as fundamental American values.

This political and constitutional discourse did not emerge fully formed and ready for either Ervin or the New Right to pick up. Along with others, Ervin developed it over time and in response to a rapidly changing set of political challenges - from opposing Brown, to fighting civil rights legislation, to protecting the unity and authority of the Democratic Party, to addressing the economic needs of the increasingly suburban and economically modern Sunbelt. As he addressed those challenges, Ervin's views changed substantially. He arrived at the Senate in 1954 as a supporter of a communitarian vision of state authority powerful enough to enforce a system of segregation that required a remarkable number of restrictions on individual autonomy. His primary political goals were to protect that system and the power of the Democratic Party. He retired from the Senate twenty years later as a wellknown supporter of individual rights and proponent of a color-blind Constitution. Ervin used his considerable skill as a constitutional theorist to justify those changes, and by doing so helped generate a network of ideas that helped guide many of his fellow conservative white southerners to a new political identity, which many continue to embrace.

University of Georgia, School of Law, USA

\section{NOTES}

1. Karl E. Campbell, Senator Sam Ervin, Last of the Founding Fathers (Chapel Hill, 2007), 77-80.

2. C. Vann Woodward, The Strange Career of Jim Crow (New York, 1974), 98-102; Pauli Murray, States' Laws on Race and Color (Athens, Ga., 1950).

3. Campbell, Senator Sam Ervin, 83-84; Anthony Badger, "The South Confronts the Court: The Southern Manifesto of 1956," Journal of Policy History 20 (January 2008): 129.

4. The most serious electoral threat Ervin faced was when Terry Sanford considered challenging him for the Democratic nomination in 1968. Sanford explained his decision not to run on the grounds that the "race issue" would have made it difficult to defeat Ervin without doing serious damage to the Democratic Party. Campbell, Senator Sam Ervin, 21113. For a description of how defenders of segregation turned from federalism to arguments 
based on individual liberty and private property, and a clear identification of their hypocrisy in making that shift, see Christopher Schmidt, "Defending the Right to Discriminate: The Libertarian Challenge to the Civil Rights Movement," in Signposts: New Directions in Southern Legal History, ed. Sally E. Hadden and Patricia Hagler Minter (Athens, 2013), $417-46$.

5. Kevin M. Kruse, White Flight: Atlanta and the Making of Modern Conservatism (Princeton, 2005), 6; Joseph Crespino, In Search of Another Country: Mississippi and the Conservative Counterrevolution (Princeton, 2007); Matthew D. Lassiter, The Silent Majority: Suburban Politics in the Sunbelt South (Princeton, 2006); Joseph E. Lowndes, From the New Deal to the New Right: Race and the Southern Origins of Modern Conservatism (New Haven, 2008).

6. Campbell, Senator Sam Ervin, 109-10.

7. Lassiter, The Silent Majority (Princeton, 2006); Kruse, White Flight, 5-6.

8. Kenneth I. Kersch, Conservatives and the Constitution: Imagining Constitutional Restoration in the Heyday of American Liberalism (New York, 2019), 30-34; Donald T. Critchlow, The Conservative Ascendancy: How the Republican Right Rose to Power in Modern America (Lawrence, KS, 2007).

9. New York Times, "Candidates Clash in Carolina Race," 10 September 1984; "Remarks at Dinner Honoring Senator Jesse Helms of North Carolina, June 16, 1983," The Public Papers of President Ronald W. Reagan, Regan Presidential Library, https://www. reaganlibrary.gov/research/speeches/61683j (accessed 5 May 2020); Kersch, Conservatives and the Constitution, 32, citing Jesses Helms, "Curb the Supreme Court," Human Events 22, no. 2 (13 July 1963): 15.

10. Raleigh News \& Observer, Under the Dome: "Helms, Edmisten Plug into 'Senator Sam," 25 January 1984. Papers of Sam Ervin, Jr., Wilson Library (Chapel Hill).

11. Logan Everett Sawyer III, "Principle and Politics in the New History of Originalism," American Journal of Legal History 57 no. 2 (June 2017): 198-22. Exceptions include Kersch, Conservatives and the Constitution; Aaron Hall, "Plant Yourselves on Its Primal Granite: Slavery, History, and the Antebellum Roots of Originalism," Law and History Review 37 no. 3 (August 2019): 743-61, Calvin Terbeek, "From Critique to Command: Brown Board of Education and the Political Development of Constitutional Originalism and the Republican Party, 1954-1971" (manuscript, 18 January 2020), all of which examine originalism before the 1970s. Those works as well as Mary Ziegler, "Grassroots Originalism: Judicial Activism Arguments, the Abortion Debate, and the Politics of Judicial Philosophy" University of Louisville Law Review 51 no. 2 (Winter 2013): 201-38, look beyond academic debates.

12. George Nash and, more recently, Ken Kersch, have shown the important role constitutional discourse played in uniting conservatives. George H. Nash, The Conservative Intellectual Movement in America Since 1945 (New York, 1976); Kersch, Conservatives and the Constitution. But originalism itself continues to be regularly characterized as a tool created by the New Right to advance its agenda, particularly in courts. See Robert Post and Reva Siegel, “Originalism as a Political Practice: The Right's Living Constitution," Fordham Law Review 75 (2006): 545.

13. As Joseph Lowndes has written, "successful . . . regime builders must transform coalitions into more deeply held collective political identities. This requires actors to 
synthesize diverse political ideas into seemingly natural frameworks over a long span of time." Lowndes, From the New Deal to the New Right, 157. Kersch's Conservatives and the Constitution applies a similar approach to show how a wide variety of conservative intellectuals, including, but certainly not limited to, originalists, used constitutional argument to construct a conservative identity that has held together a potentially fractious coalition. This article extends these insights by showing that originalism was attractive to conservative politicians because it helped solve practical problems associated with building legislative and electoral coalitions. Reuel Schiller, Forging Rivals (Cambridge, 2017) shows how legal discourse can contribute to the construction of similar frameworks outside the conservative movement.

14. Campbell, Senator Sam Ervin, 83-85.

15. Sam J. Ervin, “Alexander Hamilton's Phantom: Supreme Court Has Usurped the Power to Nullify Acts of Congress" (28 April 1955), in Vital Speeches of the Day October 15, 1955-October 1, 1956, (n.p.), 23-26.

16. Sam J. Ervin et al., "Southern Manifesto," Congressional Record 102 (12 March 1956): 4459-60; Karl E. Campbell, "Claghorn's Hammurabi: Senator Sam Ervin and Civil Rights," North Carolina Historical Review 78, no. 4 (October 2001): 431-56.

17. Campbell, Senator Sam Ervin, 83, 122, 129, 146, 148.

18. James J. Kilpatrick, “Sam Ervin, Founding Father,” Winston Salem Journal, 29 May 1970.

19. In National Surety Corporation v. Sharpe, 232 N.C. 98, 103-4 (1950), for example, Ervin interpreted the meaning of the North Carolina Constitution's "Law of the Land" clause. He said nothing about the historical circumstances surrounding the Constitution. Instead, he wrote that the language was taken from the Magna Carta, noted its similarity to the US Constitution's Due Process Clause, then primarily defined the clause's meaning by quoting a hornbook. In an analysis of a question he identified as one of first impression, he eschewed an analysis of the historical circumstances surrounding the constitutional provision and based his decision on the "manifest" design of the provision. Boney v. Board of Trustees of Kinston Graded Schools, 229 N.C. 136, 140 (1948). Though not common, there were discussions by other justices of the role original intent and meaning should play in Constitutional interpretation. Justice Barnhill in Perry v. Stancil, 237 N.C. 442 (1953) emphasized that the "fundamental principle of constitutional construction is to give effect to the intent of the framers of the organic law and the people adopting it."

20. Sam J. Ervin, "Alexander Hamilton's Phantom."

21. Ibid.; Jack M. Balkin, "The New Originalism and the Uses of History," Fordham Law Review 82 (2013): 641.

22. My definition of originalism draws on but is not the same as the definition that Lawrence B. Solum and others have used in ongoing academic debates. See Lawrence B. Solum, "Originalism and Constitutional Construction," Fordham Law Review 82 (2013): 3. My definition is narrower because I want to identify methods of constitutional interpretation that would be considered originalist if they were used in political debate. As I use the term, originalism is a method of constitutional interpretation that provides a greater role for the original intentions of the Constitution's drafters or the original meaning of the text than other theories of constitutional interpretation allow. Originalism emphasizes original intent or meaning by asserting that the meaning of a constitutional provision was fixed when it was 
drafted or ratified, and that this meaning should constrain the application of the Constitution to particular disputes. Originalism, as I use the term, asserts that extrinsic evidence from the time a provision was written can provide insights into the intentions of the drafters and the meaning of the text-insights that can definitively resolve important and contested issues of constitutional law. No one would have called Ervin an originalist during his time in public life because the term was not coined until a 1980 critique of the theory by Paul Brest. Paul Brest, "The Misconceived Quest for Original Understanding," Boston University Law Review 60, no. 2 (March 1980): 204-38. Yet it is not anachronistic to call Ervin an originalist because even though the term did not exist, the concept did. See Quentin Skinner, Regarding Method, vol. 1 of Visions of Politics (New York, 2002), 159. After 1956, Ervin consistently defined the proper role of the Court in a way that fit the concept as it was later understood by originalists. And when works appeared that are now considered part of the originalist tradition-including scholarship by Raoul Berger and Lino A. Graglia and legal opinions by Justice William Rehnquist, Ervin readily identified them as examples of his own methodology. See Sam J. Ervin Jr., "Judicial Verbicide: An Affront to the Constitution," Modern Age: A Conservative Review 25 (Summer 1981). Just as Rehnquist, Berger, and Graglia can properly be described as originalists in the years before Brest's article, so too can Ervin.

23. Ervin, "Alexander Hamilton's Phantom," 34.

24. Ibid., 25 .

25. Alexander M. Bickel, "The Original Understanding of the Segregation Decision," Harvard Law Review 69, no. 1 (November 1955): 5. William Winslow Crosskey can be considered an originalist, but his Politics and the Constitution in the History of the United States (Chicago, 1953) had little influence.

26. See Adamson v. California, 332 US 46 (1947) (Black, dissenting).

27. Dennis v. United States, 341 US 494 (1951) (Black, dissenting); Adamson v. California, 332 US 46 (1947). These decisions contributed to Ervin's support for bills that sought to strip the Supreme Court of jurisdiction over questions of civil liberties. Karl E. Campbell, "Preserving the Constitution, Guarding the Status Quo: Senator Sam Ervin and Civil Liberties," North Carolina Historical Review 78, no. 4 (October 2001): 463-64. Ervin supported the Jenner-Block bill and the States Rights Bill in 1957.

28. Bickel, "The Original Understanding," 58; Alfred H. Kelly, "The Fourteenth Amendment Reconsidered: The Segregation Question," Michigan Law Review 54, no. 8 (June 1956): 1049-86; Richard Kluger, Simple Justice: The History of Brown Board of Education and Black America's Struggle for Equality (New York, 2004); Alfred Avins, "De Facto and De Jure School Segregation: Some Reflected Light on the Fourteenth Amendment from the Civil Rights Act of 1875," Mississippi Law Journal 38, no. 2 (March 1967): 179-247 (1967); Alfred Avins, “The Equal 'Protection' of the Laws: The Original Understanding," New York Law Forum 12, no. 3 (Fall 1966): 385-429.

29. Bickel, "The Original Understanding."

30. G. Edward White, "The Evolution of Reasoned Elaboration: Jurisprudential Criticism and Social Change," Virginia Law Review 59 (February 1973): 286. Alexander Bickel, for example, certainly saw himself extending that tradition. Alexander M. Bickel, The Supreme Court and the Idea of Progress (New York, 1970), 19-30.

31. The version of process jurisprudence these scholars advanced, G. Edward White has written, "was incompatible with the brand of activism that emerged in the Warren Court." White, "Reasoned Elaboration,” 291. 
32. Learned Hand, The Bill of Rights (Cambridge, Mass., 1958): 55.

33. Herbert Wechsler, "Toward Neutral Principals and Constitutional Law," Harvard Law Review 73, no. 1 (November 1959): 26.

34. Ibid., 150-51; Philip B. Kurland, "Forward: Equal in Origin and Equal in Title to the Legislative Branches of Government," Harvard Law Review 78, no. 1 (1964): 143-76.

35. Badger, "The South Confronts the Court," 126-42; John Kyle Day, The Southern Manifesto: Massive Resistance and the Fight to Preserve Segregation (Jackson, MS, 2014); Peter Charles Hoffer, The Search for Justice (Chicago, 2019), 101-21.

36. Jason Morgan Ward, Defending White Democracy: The Making of a Segregationist Movement and the Remaking of Racial Politics, 1936-1965 (Chapel Hill, 2011); Keith M. Finley, Delaying the Dream: Southern Senators and the Fight Against Civil Rights, 1938-1965 (Baton Rouge, 2008).

37. Finley, Delaying the Dream, 5-7.

38. Day, The Southern Manifesto, vii, 4-5, 62.

39. Finley, Delaying the Dream, 9-12.

40. Ibid., 10.

41. Ibid.

42. Badger, "The South Confronts the Court," 128.

43. 'Anders Walker, The Ghost of Jim Crow: How Southern Moderates Used Brown Board of Education to Stall Civil Rights (New York, 2009); William H. Chafe, Civilities and Civil Rights: Greensboro, North Carolina, and the Black Struggle for Freedom (New York, 1981). By reactionaries I mean white southerners prepared to resist integration through violence, other lawless actions, or actions of questionable legality, including massive resistance supported by interposition. By moderates I mean white southerners who supported segregation but rejected violence, lawlessness, and massive resistance.

44. Anthony Badger, New Deal / New South (Fayetteville, 2007), 81-85. A majority of Texas's congressional delegation-one senator and seventeen representatives-did not sign the manifesto. The Texas response stemmed from both an intrastate battle over control of the Democratic Party and personal animosities among the state's politicians. Ibid., 73-78.

45. Badger, "The South Confronts the Court."

46. Day, The Southern Manifesto, 13.

47. Walker, Ghost of Jim Crow; Michal R. Belknap, Federal Law and Southern Order: Racial Violence and Constitutional Conflict in the Post-Brown South (Athens, 1995).

48. Badger, "The South Confronts the Court," 137-38.

49. "Blue Print for Resisting Integration," Papers of W. C. George, folder 99, Wilson Library (Chapel Hill).

50. Walker, Ghost of Jim Crow; Badger, "The South Confronts the Court," 133-34.

51. Ibid.

52. 'Sam J. Ervin, "The United States Congress and Civil Rights Legislation," North Carolina Law Review 42, no. 1 (1963-1904): 3.

53. Laura Kalman, Long Reach of the Sixties: LBJ, Nixon, and the Making of the Contemporary Supreme Court (New York, 2017).

54. "Remarks for Presentation at Meeting in Hillsboro," Papers of W.C. George, folder 99, Wilson Library (Chapel Hill).

55. Ibid. 
56. "Some Issues in our National Crisis: Integration, Christianity, and 'the Law of the Land," 2 June 1960, Papers of W.C. George, folder 99, Wilson Library (Chapel Hill).

57. Ibid.

58. "Speech," Papers of W.C. George, folder 99, Wilson Library (Chapel Hill).

59. Ibid.

6o. "Some Issues in our National Crisis."

61. " "Speech."

62. Day, The Southern Manifesto; Hoffer, The Search for Justice, 109.

63. Typed draft marked "Ervin" in Russell's handwriting, Richard B. Russell, Jr. Collection, III. Speech/Media, Box 27, Folder 9, "Southern Manifesto" (Athens, 1956).

64. Ibid.

65. Sam J. Ervin et al., "Southern Manifesto," 4459-60.

66. Ibid.

67. Ward, Defending White Democracy.

68. US Congress, Senate, Subcommittee on Constitutional Rights, Hearings Before the Subcommittee on Constitutional Rights of the Committee of the Judiciary, 86th Cong., 1st sess., on S. 435, Etc. (1959), 32. See also US Congress, Senate, Subcommittee on Constitutional Rights, Subcommittee on Constitutional Rights 1959 Civil Rights Act Hearing, 378-79; ibid., 383 .

69. US Congress, Senate, Committee on the Judiciary, Hearings on Civil Rights: The President's Program (S. 1731), 88th Cong., 1st sess., 1963, 180.

70. Finley, Delaying the Dream, 10.

71. Ibid., 168.

72. Ibid., 168-70. See Senator Ervin, speaking on HR 6127, on 19 June 1957, 85th Cong., 1st sess., Congressional Record 103, pt. 7: 9627-Senator Russell, speaking on HR 6127, on 2 July 1957, 85th Cong., 1st sess., Congressional Record 103, pt. 8: 10771; Senator Scott, speaking on HR 6127, on 13 July 1957, 85th Cong., 1st sess., Congressional Record 103, pt. 9: 11,611; Senator Long, speaking on HR 6127, on 15 July 1957, 85th Cong., 1st sess., Congressional Record 103, pt. 9: 11,683; Senator Byrd, speaking on HR 6127, on 16 July 1957, 85th Cong., 1st sess., Congressional Record 103, pt. 9: 11,817; Senator Russell, speaking on HR 6127, on 18 July 1957, 85th Cong., 1st sess., Congressional Record 103, pt. 9: 12,073-74; Senator Talmage, speaking on HR 6127, on 28 August 1957, 85th Cong., 1st sess., Congressional Record 103, pt. 12: 16,216.

73. Senator Ervin, speaking on HR 6127, on 8 July 1957, 85th Cong., 1st sess., Congressional Record 103, pt. 8: 10999-11000.

74. Ibid., 10997; ibid., on 10 July 1957, 11201.

75. Senator Ervin, speaking on HR 6127, on 8 July 1957, 85th Cong., 1st sess., Congressional Record 103 pt. 8: 10998.

76. Ibid., 10995; ibid., 10999; Senator Ervin, speaking on HR 6127, on 10 July 1957, 85th Cong., 1st sess., Congressional Record 103 pt. 8: 11201; Senator Ervin, speaking on HR 8315, on 10 March 2019, 85th Cong., 2nd sess., Congressional Record 106, pt. 4: 5157.

77. Senator Ervin, speaking on HR 6127, on 8 July 1957, 85th Cong., 1st sess., Congressional Record 103 pt. 8: 10966.

78. Senator Ervin, speaking on HR 6127, on 10 July 1957, 85th Cong., 1st sess., Congressional Record 103 pt. 8: 11203-4. 
79. Article 3, section 2, of the Constitution says: "The judicial power shall extend to all cases, in law and equity, arising under this Constitution, the laws of the United States, and treaties made ... under their authority." Article 3, section 2, also says that "the trial of all crimes, except in cases of impeachment, shall be by jury."

80. 'Senator Ervin, speaking on HR 6127, on 8 July 1957, 85th Cong., 1st sess., Congressional Record 103 pt. 8: 11001.

81. Ibid.

82. Chris W. Schmidt, The Sit-Ins (Chicago, 2018), 152-67, provides an insightful analysis of the intersecting legal and political issues surrounding the 1964 Civil Rights act.

83. Finley, Delaying the Dream, 239-40.

84. Ibid., 255-60.

85. Ibid., 253.

86. Senator Hill, speaking on HR 7152, on 9 March 1964, 88th Cong., 2nd sess., Congressional Record 110 pt. 4: 4759; Senator Hill, speaking on HR 7152, on 11 May 1964, 88th Cong., 2nd sess., Congressional Record 110 pt. 8: 10,524; Senator Byrd, speaking on HR 7152, on 20 May 1964, 88th Cong., 2nd sess., Congressional Record 110 pt. 9: 11,522. Finley, Delaying the Dream, 257.

87. 'Schmidt, "Defending the Right to Discriminate."

88. Ibid.

89. Ervin, "The United States Congress," 3-15.

90. US Congress, Senate, Committee on the Judiciary, Civil Rights the President's Program, 304. At other moments, Ervin directed the attorney general's attention to a legal treatise that in his opinion "correctly state[d] the fundamental principle of constitutional construction," or interpretation: "to give effect to the intent of the framers of the organic law and of the people adopting it." Thus to determine the meaning of the Fourteenth Amendment, Ervin continued, "We must ascertain the intent of those who framed and ratified it." Id at 180 .

91. Sam J. Ervin Jr., "The Role of the Supreme Court as the Interpreter of the Constitution," Alabama Lawyer 26, no. 4 (October 1965): 389-99.

92. Ervin, "United States Congress and Civil Rights Legislation," 4. Title II was upheld 9-o in Heart of Atlanta Motel, Inc. US, 379 US 241 (1964) and Katzenback McClung, 379 US 294 (1964).

93. Ibid., 3 .

94. Ibid., 4 .

95. Ibid., 8, citing Wickard Filburn, 317 US 111 (1942).

96. Ibid., 7-10.

97. Ibid., 10.

98. Ervin was not alone in adopting this strategy. Schmidt, The Sit-Ins, 163.

99. Ervin, "United States Congress and Civil Rights Legislation," 10.

100. Ibid.

101. Ibid., 9-10, citing Robert Bork, "Civil Rights-A Challenge," New Republic, 31 August 1963, 21-22.

102. Ibid., 10.

103. Finley, Delaying the Dream, 259-60.

104. Ibid., 275. 
105. Ibid., 274.

106. Kruse, White Flight, 251-53; Matthew D. Lassiter, "Political History Beyond the Red-Blue Divide," Journal of American History 98, no. 3 (December 2011): 760-64.

107. As a result of the act, the percentage of registered black voters climbed from 24.4 percent to approximately 60 percent between 1964 and 1969. By 1970, there were more than one million black voters registered in the South. Hugh Davis Graham, Collision Course: The Strange Convergence of Affirmative Action and Immigration Policy in America (New York), 26.

108. Sam J. Ervin Jr., "The Truth Respecting the Highly Praised and Constitutionally Devious Voting Rights Act," Cumberland Law Review 12, no. 2 (1981-82): 261-81; Sam J. Ervin Jr., Preserving the Constitution: The Autobiography of Senator Sam J. Ervin, Jr. (Charlottesville, 1984), 178.

109. Kruse, White Flight, 253-55; Lassiter, "Political History," 760-64.

110. US Congress, Senate, Committee on the Judiciary, Nomination of Warren E. Burger, of Virginia, to be Chief Justice of the United States, 91st Cong., 1st sess., 1969, 38, in The Supreme Court of the United States: Hearings and Reports on Successful and Unsuccessful Nominations of Supreme Court Justices by the Senate Judiciary Community, 1916-1972, vol. 7, comp. Roy M. Mersky and J. Myron Jacobstein (Buffalo, 1975).

111. Ibid.

112. Sam J. Ervin Jr. and Ramsey Clark, Role of the Supreme Court: Policymaker or Adjudicator? (Washington, DC, 1970), 8.

113. Ervin, "Judicial Verbicide," 241.

114. Ibid., 239.

115. US Congress, Senate, Committee on the Judiciary, Civil Rights the President's Program.

116. Brief for Sam J. Ervin Jr. et al. as Amici Curiae Supporting Respondents, Swann Charlotte-Mecklenburg Bd. of Educ., 402 US 1 (1971), 1970 WL 136786, at 22.

117. Ervin, Preserving the Constitution, 164.

118. Kruse, White Flight, 253-55; Lassiter, "Political History Beyond the Red-Blue Divide," $760-64$.

119. Campbell, Senator Sam Ervin, 255; ibid., 256; ibid., 274-75.

120. Ervin, Preserving the Constitution, $\mathrm{x}$.

121. Brief for Americans for Public Schools et al. as Amicus Curiae Supporting Respondents, Flast Cohen, 392 US 83 (1968), 1967 WL 113850; Sam Ervin Jr., "Mrs. Frothingham and Federal Aid to Church Schools," North Dakota Law Review 43, no. 4 (Summer 1967): 691.

122. Sam J. Ervin Jr., "Uncompensated Counsel: They Do Not Meet the Constitutional Mandate," American Bar Association Journal, 49, no. 5 (May 1963): 435.

123. Sam J. Ervin Jr., "The Legislative Role in Bail Reform," George Washington Law Review 35, no. 3 (March 1967): 429; Sam J. Ervin Jr., "Foreword: Preventitive Detention: A Step Backward for Criminal Justice," Harvard Civil Rights and Civil Liberties Law Review 6, no. 2 (March 1971): 291.

124. Karl E. Campbell, "Preserving the Constitution, Guarding the Status Quo: Senator Sam Ervin and Civil Liberties," North Carolina Historical Review 78, no. 4 (October 2001): $457-82$. 
125. Sam J. Ervin Jr., "Miranda Arizona: A Decision Based on Excessive and Visionary Solicitude for the Accused," American Criminal Law Quarterly 5, no. 3 (Spring 1967): 125; Ervin, Preserving the Constitution, 146-47; ibid., 126-27; Roe v. Wade 410 US 113 (1973).

126. Sam Ervin Jr., Address to the Board of Directors of the National Association of Manufacturers, 20 September 1968, Ervin Papers, Series B, Folder 695; Paul R. Clancy, Just a Country Lawyer: A Biography of Senator Sam Ervin (Bloomington, 1974), 248.

127. Senator Ervin, speaking on S J Res 148, on 20 September 1966, 89th Cong., 2nd sess., Congressional Record 112, pt. 17:23122-45. Ervin made no explicitly originalist claims in the speech because the debate was over a constitutional amendment and there was thus no dispute over the meaning of the Constitution. But Ervin's deference to the judgment of the founding fathers on the importance of the separation of church and state is clear.

128. Senator Ervin, speaking on S J Res 148, on 20 September 1966, 89th Cong., 2nd sess., Congressional Record 112, pt. 17:23122. 